Bangladesh J. Bot. 49(1): 125-134, 2020 (March)

\title{
OPTIMUM VEGETATIVE GROWTH CONDITIONS AND GENETIC DIVERSITY IN DIFFERENT STRAINS OF PLEUROTUS SALMONEASTRAMINEUS L.J.N. VASSILZEVA
}

\author{
Nuhu Alam* and Farhana Rahman \\ Department of Botany, Faculty of Biological Sciences, Jahangirnagar University, \\ Savar, Dhaka-1342, Bangladesh
}

Keywords: ITS sequence, Molecular identification, Pleurotus salmoneostramineus, Phylogenetic relation, RAPD, Vegetative growth

\begin{abstract}
This experiment was undertaken to depict the favourable condition for mycelial growth, molecular identification and phylogenetic relationship of the selected strains of Pleurotus salmoneostramineus. Suitable temperature and $\mathrm{pH}$ were obtained at $25^{\circ} \mathrm{C}$ and 6, respectively. Mushroom complete, glucose peptone and yeast malt extract culture media were favorable, while Hennerberg and Hoppkins were unfavorable. Dextrin was the best and xylose was the less effective carbon sources. Inorganic nitrogen sources were less effective for the mycelial growth of $P$. salmoneostramineus. The sequences of internal transcribed spacer (ITS) region of selected strains revealed that the total length ranged from 614 to $663 \mathrm{bp}$. The size of the ITS1 and ITS2 regions varied among the strains. Sequence analysis showed that 5.8S of rDNA sequences were identical. Phylogenetic tree of the ITS region sequences indicated that strains of $P$. salmoneostramineus belong to same cluster. The reciprocal homologies of the ITS region sequences ranged from 98 to $100 \%$. The strains of $P$. salmoneostramineus were also analyzed by random amplification of polymorphic DNA (RAPD) with 20 arbitrary primers. RAPD results suggested that tested strains of $P$. salmoneostramineus were genetically similar with some variations, thus it could be concluded that RAPD and ITS techniques were well competent for detecting the genetic diversity of all tested strains of $P$. salmoneostramineus.
\end{abstract}

\section{Introduction}

Pleurotus salmoneostramineus LJ.N. Vassilzeva commonly known as pink oyster mushroom grows on dead deciduous plants (Murakami and Takemaru 1990). It is becoming popular due to attractive color, sustainable yield, delicious test, and unique texture. $P$. salmoneostramineus is rich in protein, lipids, fiber, carbohydrates, vitamins and contains an abundant amount of essential amino acids (Hossain et al. 2007, Yoon et al. 2012).

Pink oyster mushroom has complicated morphological variations of basidiospores, resulting in taxonomic confusion and difficulties in delimiting species boundaries (Venturella 2000). It has a tetrapolar system of sexual compatibility and a well defined haplo dikaryotic life cycle. Mycelium cultivation is enhanced by different environmental and nutritional factors as well as propagation of mycelium is an earlier and essential step to cultivate fruiting bodies of mushrooms.

Investigation of genetic diversity is necessary to distinguish genotypes of $P$. salmoneostramineus when seeking traits of interest and to identify strains with high yield potential. Various molecular genetics tools have been introduced for the verification of fungi, such as restriction fragment length polymorphism (RFLP), RAPD, and small subunit ribosomal DNA (SSU rDNA), and ITS sequence analyses. Recent molecular phylogenetic studies have demonstrated that the ITS region of genomic DNA is very useful for assessing phylogenetic relationships at lower taxonomic levels (Park et al. 2004, Tuchwell et al. 2005, Cho et al. 2010).

\footnotetext{
*Author for correspondence:<mnabotju@yahoo.com>.
} 
Genetic analysis on the mushroom species has shown that RAPD was superior to rDNA sequencebased methods when distinguishing strains within species. RAPD was particularly successful when applied for verifying mushroom strains from various hosts with a wide range of geographical origins (Alam et al. 2010). Hence, the present study was undertaken to investigate molecular identification and genomic polymorphism among the selected strains of $P$. salmoneostramineus. Experiments also explored the physical and chemical conditions for the mycelial growth.

\section{Materials and Methods}

Five cultivated strains of Pleurotus salmoneostramineus such as IUM-1794, IUM-2130, IUM3705, IUM-3975 and IUM-4146 were obtained from culture collection of DNA Bank of Mushrooms (CCDBM), Division of Life Sciences, Incheon National University, Korea and acquired accession number Incheon University Mushroom (IUM), which was collected from the different ecological regions of Korea, Taiwan and Thailand (Table 1). Experiment was conducted in the laboratory of mycology and plant pathology, Department of Botany, Jahangirnagar University.

Table 1. List of IUM and NCBI GenBank strains used for the studies on molecular phylogenetic relationships.

\begin{tabular}{|c|c|c|}
\hline $\begin{array}{l}\text { Oyster } \\
\text { mushrooms }\end{array}$ & $\begin{array}{l}\text { IUM strains and sources } \\
\text { of collections }\end{array}$ & $\begin{array}{l}\text { NCBI GenBank } \\
\text { strains }\end{array}$ \\
\hline P. salmoneostramineus & $\begin{array}{l}\text { Korea (IUM-1794, } 3705 \text { and 3975), Taiwan, } \\
\text { IUM-4146 and Thailand, IUM-2130 }\end{array}$ & $\begin{array}{l}\text { AY-265843, AY-265844 } \\
\text { and AY-636057 }\end{array}$ \\
\hline P. citrinopileatus & $\begin{array}{l}\text { Bangladesh (IUM-4311 and 4312), China (IUM- } \\
0557 \text { and 2652), Korea (IUM-3967 and 4502) } \\
\text { and Taiwan (IUM-1307 and 4152) }\end{array}$ & $\begin{array}{l}\text { AB-115043, } \\
\text { and DQ-77889 }\end{array}$ \\
\hline P. eryngii & $\begin{array}{l}\text { China (IUM-3487, 3501, } 3865 \text { and 3920), Japan } \\
\text { (IUM-2253 and 2263), Korea (IUM-1550, 2106, } \\
3140 \text { and 3939), and Taiwan (IUM-2126, 2137, } \\
2143 \text { and 2161) }\end{array}$ & $\begin{array}{l}\text { AY-581425, EF-514246, } \\
\text { EU-395845 }\end{array}$ \\
\hline P. nebrodensis & $\begin{array}{l}\text { China (IUM-1381, 1495, 2210, 2235, 3061, } \\
3424,3514,3914 \text { and 3918) }\end{array}$ & $\begin{array}{l}\text { AY-581429, AY-581430 } \\
\text { and AY-581431 }\end{array}$ \\
\hline P. ostreatus & $\begin{array}{l}\text { China (IUM-1932, } 2013 \text { and 2036), Korea } \\
\text { (IUM-1316, 1319, } 1395 \text { and 1721), and Taiwan } \\
\text { (IUM-2679, 4143, } 4162 \text { and 4171) }\end{array}$ & $\begin{array}{l}\mathrm{AB}-115051, \mathrm{AF}-423120 \\
\text { and DQ-077884 }\end{array}$ \\
\hline
\end{tabular}

Six different temperatures such as $10,15,20,25,30,35^{\circ} \mathrm{C}$ and $\mathrm{pH} 4,5,6,7,8$ and 9 were used to find out the optimum temperature for the mycelial growth of $P$. salmoneostramineus. The measurement of mycelial growth was performed according to the methods described by Alam et al. (2010). Ten different culture media (Czapek dox, glucose peptone, glucose tryptone, Hamada, Hennerberg, Hoppkins, Lilly, mushroom complete, potato dextrose agar and yeast malt extract) were used to investigate the mycelial growth of $P$. salmoneostramineus. The compositions of culture media were prepared according to the method described by Alam et al. (2009). Carbon and nitrogen sources experiment was performed on the basal medium supplemented with each of ten carbon sources (Dextrin, fructose, galactose, glucose, lactose, maltose, mannose, sorbitol, sucrose and xylose) and ten nitrogen sources (Ammonium phosphate, arginine, ammonium acetate, calcium nitrate, glycine, histidine, methionine, potassium nitrate and urea). 
Fresh mycelia of the selected strains of $P$. salmoneostramineus were collected from the 10 days old culture on potato dextrose agar (PDA) medium and were frozen with liquid nitrogen and genomic DNA was extracted according to the procedure of Lee and Taylor (1990).

Genomic DNA was amplified by the RAPD technique (Williams et al. 1990) in which 20 sorts of arbitrary 10-base oligonucleotide primers was used to produce amplified fragments. RAPD-PCR reaction was performed using a thermal cycler with an initial denaturation stage of 5 min at $94^{\circ} \mathrm{C}$, followed by 35 cycles of denaturation for $1 \mathrm{~min}$ at $94^{\circ} \mathrm{C}$, annealing for $1 \mathrm{~min}$ at $36^{\circ} \mathrm{C}$, extension for $2 \mathrm{~min}$ at $72^{\circ} \mathrm{C}$ and a final extension for $7 \mathrm{~min}$ at $72^{\circ} \mathrm{C}$. RAPD products were electrophoresed on $1.4 \%$ agarose gel in $1 \times \mathrm{TAE}$ buffer for $1.15 \mathrm{hr}$ at $100 \mathrm{v}$, with a $1 \mathrm{~kb}$ DNA ladder as a size marker and then stained while agitated in an $\mathrm{EtBr}$ solution $(0.5 \% \mu \mathrm{g} / \mathrm{ml})$. The stained gels were visualized and photographed using a UV transilluminator. RAPD bands were recorded as present (1) or absent (0) to generate the data matrix. The similarity coefficients (S) were calculated between isolates across bands for all primers using the formula $\mathrm{S}=2 \mathrm{Nxy} /(\mathrm{Nx}+\mathrm{Ny})$, where $\mathrm{Nx}$ and $\mathrm{Ny}$ are the number of bands shared by the two strains (Nei and Li 1979).

\section{Results and Discussion}

Effects of temperature for the vegetative growth of $P$. salmoneostramineus presented in Table 2 shows that the highest average mycelial growth $(86.82 \mathrm{~mm})$ was at $25^{\circ} \mathrm{C}$ and lowest $(9.33 \mathrm{~mm})$ at $10^{\circ} \mathrm{C}$. Therefore, experimental results indicated that $25^{\circ} \mathrm{C}$ was the optimum temperature for the mycelial growth of $P$. salmoneostramineus. This experimental finding is comparable to the previous study of Alam et al. (2010), who reported that $25^{\circ} \mathrm{C}$ is the optimum temperature for the mycelial growth of oyster mushrooms.

Table 2. Effect of temperature on the mycelial growth in different strains of Pleurotus salmoneostramineus.

\begin{tabular}{lcccccc}
\hline \multirow{2}{*}{ Strains } & \multicolumn{7}{c}{ Mycelial growth $(\mathrm{mm})^{*}$} \\
\cline { 2 - 7 } & $10^{\circ} \mathrm{C}$ & $15^{\circ} \mathrm{C}$ & $20^{\circ} \mathrm{C}$ & $25^{\circ} \mathrm{C}$ & $30^{\circ} \mathrm{C}$ & $35^{\circ} \mathrm{C}$ \\
\hline IUM-1794 & $9.08 \pm 1.0$ & $45.67 \pm 1.4$ & $62.50 \pm 1.0$ & $87.00 \pm 0.0$ & $63.92 \pm 5.3$ & $24.67 \pm 1.1$ \\
IUM-2130 & $8.83 \pm 0.8$ & $48.58 \pm 4.4$ & $66.67 \pm 0.8$ & $87.00 \pm 0.0$ & $76.67 \pm 0.4$ & $65.42 \pm 6.5$ \\
IUM-3705 & $6.25 \pm 0.5$ & $35.58 \pm 1.4$ & $67.42 \pm 0.5$ & $86.08 \pm 0.5$ & $67.00 \pm 0.0$ & $22.42 \pm 6.2$ \\
IUM-3975 & $10.58 \pm 1.4$ & $41.58 \pm 5.1$ & $58.83 \pm 1.4$ & $87.00 \pm 0.0$ & $75.83 \pm 0.6$ & $75.83 \pm 0.6$ \\
IUM-4146 & $11.92 \pm 1.2$ & $36.33 \pm 3.5$ & $70.92 \pm 1.2$ & $87.00 \pm 0.0$ & $66.25 \pm 0.3$ & $41.08 \pm 5.3$ \\
MEAN & $9.33 \pm 0.9$ & $41.55 \pm 3.2$ & $65.21 \pm 0.9$ & $86.82 \pm 0.1$ & $69.93 \pm 1.3$ & $45.88 \pm 3.9$ \\
\hline
\end{tabular}

*Mean of 3 replications.

$\mathrm{pH}$ value at the range of $4-9$ was studied to find out the favourable culture conditions for the mycelial growth. The highest radial growth of mycelium was found at $\mathrm{pH} 6$ (Table 3). This result is in agreement with the data collection reported by Hur (2008) who studied that the cultural characteristics and log-mediated cultivation of Phellius linteus and found that the $\mathrm{pH}$ value 6 was the best. Present results indicated that $P$. salmoneostramineus grew well at acidic or neutral conditions.

The results of effects of culture media on the mycelial growth in different strains of $P$. salmoneostramineus, indicated that mushroom complete, glucose peptone and yeast-malt extract media were the most favorable, while Hennerberg and Hoppkins were the unfavorable culture media for the vegetative growth of $P$. salmoneostramineus (Table 4). Hur (2008) reported that the 
excellent mycelial growth of $P$. linteus was in mushroom complete medium. This result is more or less similar to the present findings.

Table 3. Effect of pH on the mycelial growth in different strains of Pleurotus salmoneostramineus.

\begin{tabular}{lcccccc}
\hline \multirow{2}{*}{ Strains } & \multicolumn{7}{c}{ Mycelial growth $(\mathrm{mm})^{*}$} \\
\cline { 2 - 7 } & $\mathrm{pH} \mathrm{4}$ & $\mathrm{pH} \mathrm{5}$ & $\mathrm{pH} \mathrm{6}$ & $\mathrm{pH} \mathrm{7}$ & $\mathrm{pH} \mathrm{8}$ & $\mathrm{pH} \mathrm{9}$ \\
\hline IUM-1794 & $44.17 \pm 4.5$ & $76.25 \pm 0.4$ & $87.00 \pm 0.0$ & $81.17 \pm 1.4$ & $76.78 \pm 0.4$ & $57.33 \pm 2.5$ \\
IUM-2130 & $61.75 \pm 2.2$ & $76.50 \pm 0.4$ & $86.83 \pm 0.3$ & $82.58 \pm 0.3$ & $76.67 \pm 0.4$ & $67.00 \pm 0.0$ \\
IUM-3705 & $49.33 \pm 1.6$ & $66.58 \pm 0.3$ & $86.83 \pm 0.3$ & $77.42 \pm 5.0$ & $74.92 \pm 0.2$ & $59.25 \pm 0.9$ \\
IUM-3975 & $34.75 \pm 1.2$ & $65.92 \pm 0.3$ & $87.00 \pm 0.0$ & $83.78 \pm 2.8$ & $74.33 \pm 2.0$ & $52.89 \pm 1.6$ \\
IUM-4146 & $35.25 \pm 0.7$ & $56.92 \pm 0.2$ & $86.75 \pm 0.5$ & $79.67 \pm 4.2$ & $77.00 \pm 0.0$ & $37.22 \pm 0.7$ \\
MEAN & $44.45 \pm 2.1$ & $68.43 \pm 0.3$ & $86.88 \pm 0.2$ & $80.92 \pm 2.7$ & $75.94 \pm 0.6$ & $54.74 \pm 1.1$ \\
\hline
\end{tabular}

*Mean of 3 replications.

The results of the effect of carbon sources on the mycelia growth in different strains of $P$. salmoneostramineus have been presented in Table 5 indicated that dextrin was the best, while xylose was the most unfavourable carbon sources for the mycelial propagation of $P$. salmoneostramineus. This result is similar to that of Shim et al. (2005). Ten different nitrogen sources were assayed and the results showed that arginine was the best, whereas lowest mycelial growth was recorded in histidine (Table 6). These experimental findings are comparable to the previous studies on oyster mushrooms (Alam et al. 2010). Shim et al. (2005) reported that glycine was the most favorable nitrogen source, this result is not similar to the present findings. They also clarified that histidine was the most unfavorable nitrogen sources for the mycelial growth of Macrolepiota procera, which is similar to the present result. Results suggested that carbon and organic nitrogen sources are effective for mycelial propagation of mushrooms.

To study the molecular identification and genetic variation of selected strains of $P$. salmoneostramineus, the ITS region was amplified using ITS1 and ITS4 primers and sequenced. The results indicated that a length polymorphism at the sequence level ranged from 614 to $663 \mathrm{bp}$. The size of the ITS1 and ITS2 regions varied among the strains from 200 to 244 and 177 to 203 bp, respectively. Total C + G and A + T contents of ITS region varied from 39.5 to 40.9 and 58.5 to $60.5 \%$. Sequence analysis showed that the $5.8 \mathrm{~S}$ rDNA sequence was identical (154 bp) for all of the tested strains of $P$. salmoneostramineus (Table 7).

Phylogenetic tree based on the nucleotide sequences of the ITS regions in 62 different IUM and NCBI GenBank strains of $P$. citrinopileatus, $P$. eryngii, $P$. nebrodensis, $P$. ostreatus and $P$. salmoneostramineus was constructed by neighbor joining method. The phylogenetic tree was separated into 11 groups (Fig. 1). Eight different including IUM and NCBI GenBank strains of $P$. salmoneostramineus also belong to single cluster. IUM-3975 (Korea) strain is similar to NCBI GenBank strains. A maximum similarity was observed between IUM-4146 (Taiwan) and IUM1794 (Korea), and IUM-3705 (Korea) and IUM-2130 (Tailand). Reciprocal homologies of the ITS region sequences ranged from 98 to $100 \%$. The sequencing data of the selected IUM strains of $P$. citrinopileatus, $P$. eryngii, $P$. nebrodensis, $P$. ostreatus and NCBI GenBank strain were used as control strain for the comparative studies on phylogenetic relationships with the selected strain of $P$. salmoneostramineus. The results indicated that all the individual species of oyster mushrooms belongs to single major cluster. The results also indicated that most of the individual species of NCBI Genbank strains were very similar to IUM tested strains. 

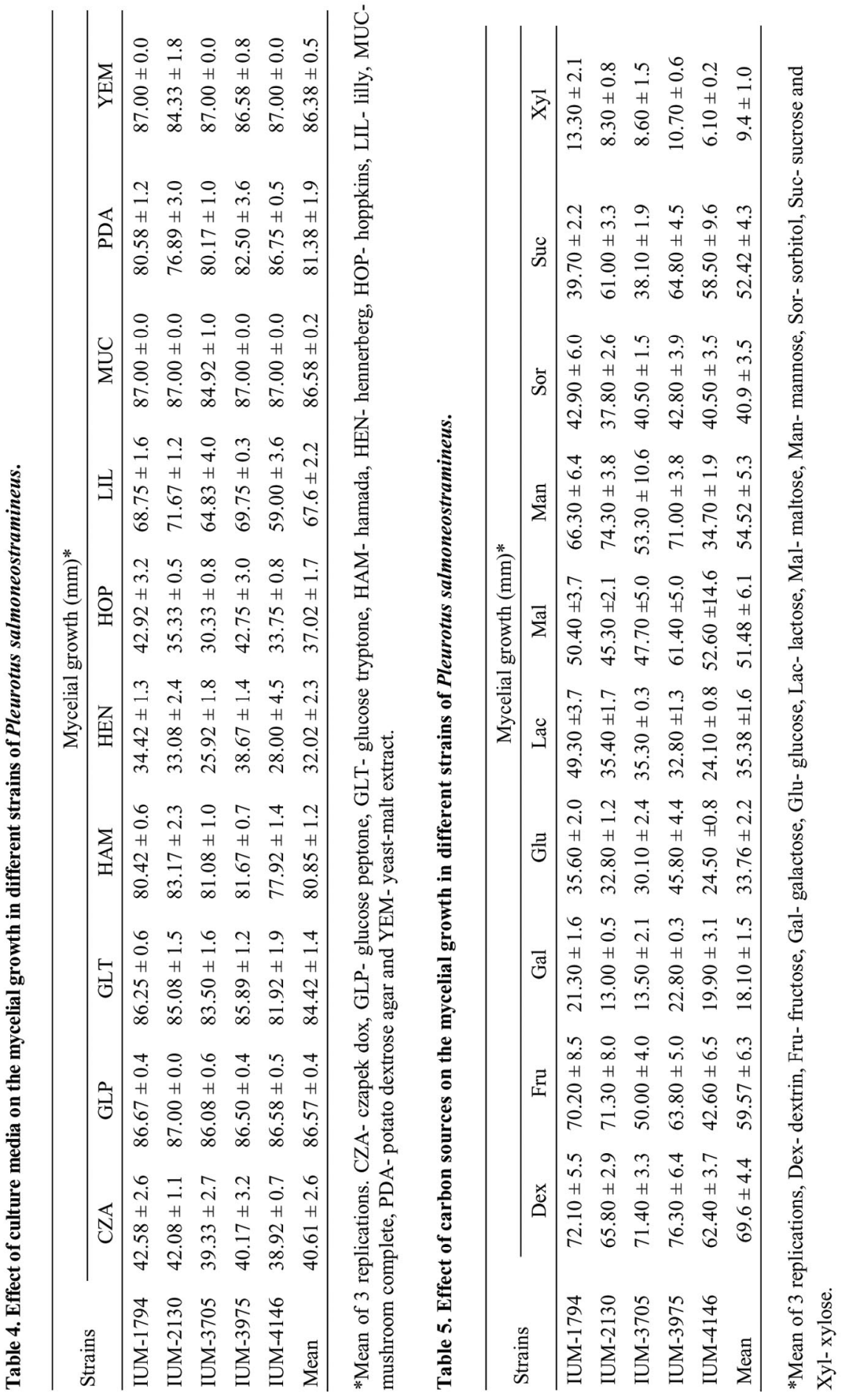





Table 7. Nucleotide distribution, ITS1, 5.8S, and ITS2 of rDNA sequences in different strains of $P$. salmoneostramineus.

\begin{tabular}{lcccccccccc}
\hline Strains & \multicolumn{4}{c}{ Nucleotide distribution (bp) } & \multicolumn{4}{c}{ Sequence information (bp) } \\
\cline { 2 - 10 } & A & C & G & T & G+C & A+T & ITS1 & $5.8 S$ & ITS2 & Length \\
\hline IUM-1794 & 153 & 98 & 154 & 220 & 40.3 & 59.7 & 221 & 154 & 177 & 625 \\
IUM-2130 & 150 & 122 & 129 & 215 & 40.7 & 59.3 & 200 & 154 & 196 & 616 \\
IUM-3705 & 145 & 126 & 125 & 218 & 40.9 & 59.1 & 220 & 154 & 199 & 614 \\
IUM-3975 & 169 & 132 & 130 & 232 & 39.5 & 60.5 & 244 & 154 & 203 & 663 \\
IUM-4146 & 149 & 115 & 142 & 213 & 41.5 & 58.5 & 233 & 154 & 181 & 619 \\
\hline
\end{tabular}

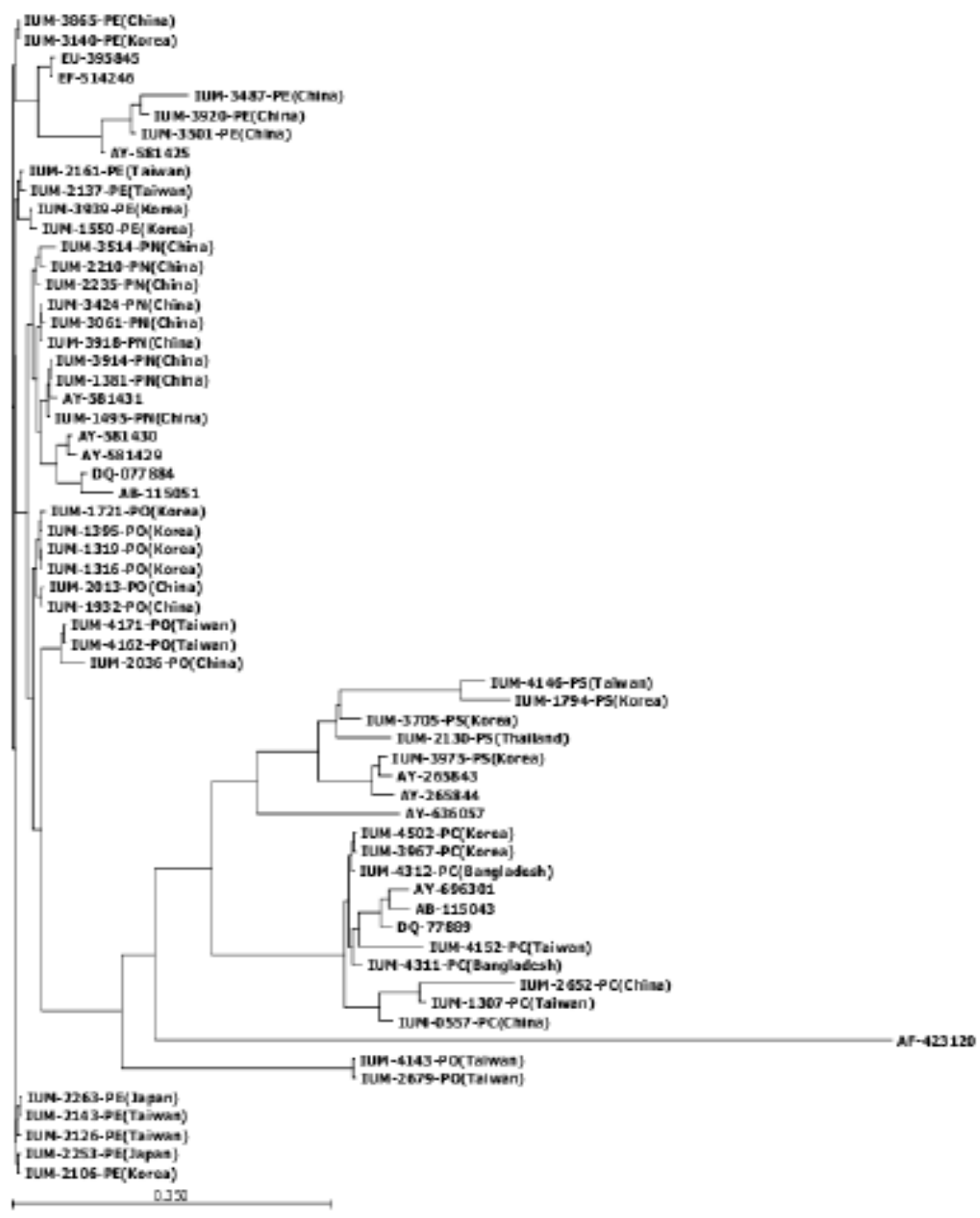

Fig. 1. Phylogenetic tree of sixty-two strains of Pleurotus spp. Based on the nucleotide sequences of the ITS regions using neighbor joining method with 1,000 bootstrapping. PC- P. citrinopileatus, PE- P. eryngii, PN- P. nebrodensis, PO- P. ostreatus and PS- P. salmoneostramineus. 
The ITS region is relatively short and can be easily amplified by PCR using universal single primer pairs. Genetic distance exhibited high level of similarity with identical ITS sequences. The size variation was caused by differences in the number of nucleotides, revealing that these strains are clearly distinguishable from each other based on the ecological distribution, substitution, and insertion or deletion polymorphisms of the base position (Ro et al. 2007). White et al. (1990) reported that ITS sequences are genetically constant or show little variation within species, but vary between species in a genus. The genetic diversity detected within groups is probably due to an efficient gene flow and to a high genetic compatibility within the strains tested. These results are supported and comparable to the study made by Bruns et al. (1991) and Zervakis et al. (2001).

Twenty sorts' arbitrary 10 base oligonucleotide primers were used to amplify the segments of DNA in five IUM strains of $P$. salmoneostramineus. Among the tested primers, ten primers, namely OPA-1, 2, 3, 4, 7, 8, 9, 10, 11 and 13 were found to be efficient for amplifying the genomic DNA. These efficient primers showed significant band profiles on the t ested strains and high possibilities to screening of each strain (Figs. 2, 3 and 4). RAPD-PCR generated distinct multiple products showing considerable variability among the tested strains. The number of amplified bands was variable depending on the primers or the strains. The size of these polymorphic fragments was obtained in the range of 0.2 to $2.3 \mathrm{~kb}$. Polymorphism of DNA bands

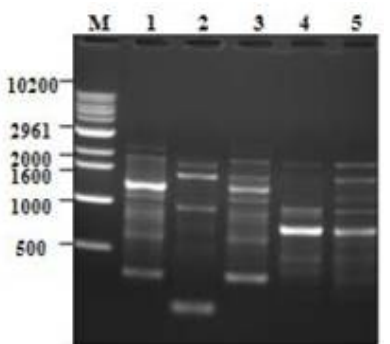

Fig. 2. RAPD profiles in different strains of $P$. salmoneostramineus with OPA-1 primer. Mmolecular size marker (1 kb DNA ladder), lane 1- IUM-1794, lane 2- IUM-3705, lane 3- IUM3975, lane 4- IUM-2130 and lane 5- IUM-4146.

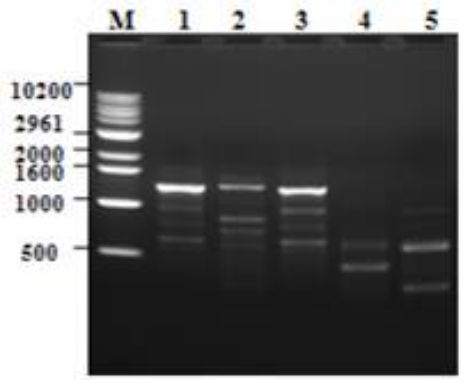

Fig. 4. RAPD profiles in different strains of $P$. salmoneostramineus with OPA-7 primer. Mmolecular size marker (1 kb DNA ladder), lane 1IUM-1794, lane 2- IUM-3705, lane 3- IUM3975, lane 4- IUM-2130 and lane 5- IUM-4146.

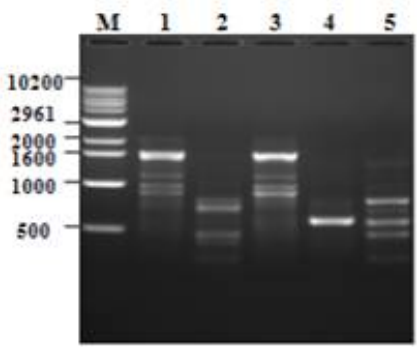

Fig. 3. RAPD profiles in different strains of $P$. salmoneostramineus with OPA-3 primer. Mmolecular size marker (1 kb DNA ladder), lane 1- IUM-1794, lane 2- IUM-3705, lane 3- IUM3975, lane 4- IUM-2130 and lane 5- IUM-4146.

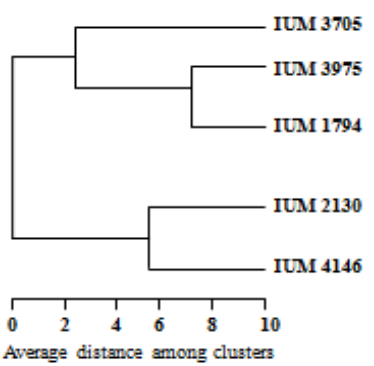

Fig. 5. Dendrogram constructed based on the random amplification of polymorphic DNA markers of $P$. salmoneostramineus strains determined by the average linkage cluster RAPD-PCR generated distinct multiple products showing considerable variability among the tested strains. 
showed the same characters in the replication tests. Therefore, if a certain strain is tested for DNA polymorphisms using the same primers, it could be identified whether the strain is the similar or not. To maximize the specificity of polymorphic patterns a combined dendrogram was constructed by using RAPD-PCR amplified bands obtained from the ten RAPD primers. Two putative groups among the 5 strains of $P$. salmoneostramineus were obtained by cluster analysis based on banding patterns and size of amplified products (Fig. 5). Among the five IUM strains, 98-100\% similarities were observed between IUM-1794 (Korea), IUM-3975 (Korea), and IUM-3705 (Korea) and IUM2130 (Thailand) and IUM-4146 (Taiwan). These results are comparable to the findings reported by Alam et al. (2010). Results on RAPD analysis were similar from the results obtained by the analysis of ITS region sequences. Strain selection and development of a molecular map of breeding interest would be realistic way to improve yield and quality of pink oyster mushrooms.

RAPD primers are useful tool for clarifying the genetic relationships among strains (Alam et al. 2009). Favourable physicochemical conditions for the vegetative growth of $P$. salmoneostramineus, thus the basic information obtained from this study could be useful to make database analysis as well as for farmers and policy makers to make protocol for mass cultivation of mushrooms. Oyster mushroom has complicated morphological variations of basidiospores, resulting in taxonomic confusion and difficulties in delimiting species boundaries. On the basis of the experimental results on molecular characterization it could be concluded that tested strains identified as pink oyster mushroom, which were genetically similar with some variations, RAPD and ITS techniques were well suited for detecting the genetic diversity.

\section{References}

Alam N, Shim MJ, Lee MW, Shin PG, Yoo YB and Lee TS 2009. Vegetative growth and phylogenetic relationship of commercially cultivated strains of Pleurotus eryngii based on ITS sequence and RAPD. Mycobiology 37: 258-266.

Alam N, Lee JS and Lee TS 2010. Mycelial growth conditions and molecular phylogenetic relationships of Pleurotus ostreatus. World Appl. Sci. J. 9(8): 928-937.

Alam N, Yoon KN, Cha YJ, Kim JH, Lee KR and Lee TS 2011. Appraisal of the antioxidant, phenolic compounds concentration, xanthine oxidase and tyrosinase inhibitory activities of Pleurotus salmoneostramineus. Afr. J. Agric. Res. 6(6): 1555-1563.

Bruns TD, White TJ and Taylor JW 1991. Fungal molecular systematics. Ann. Rev. Ecol. Systemat. 22: 525564.

Cho HJ, Lee JS, Yoon KN, Alam N, Lee KR, Shim MJ, Lee MW, Cheong JC, Shin PG, Yoo YB, Lee UY and Lee TS 2010. Comparative molecular phylogenetic relationships in different strains of Pleurotus spp. Kor. J. Mycol. 38(2): 112-119.

Felsenstein, J. 1985. Confidence limit on phylogenies: an approach using the bootstrap. Evolution 39: 783791.

Hossain MS, Alam N, Amin SMR, Basunia MA and Rahman A 2007. Essential fatty acid contents of Pleurotusostreatus, Ganoderma lucidum andAgaricusbisporus. Bangladesh J. Mushroom. 1(1): 1-7.

Hur H 2008. Cultural characteristics and log-mediated cultivation of the medicinal mushroom, Phellinus linteus. Mycobiology 36(2): 81-87.

Lee SB and Taylor JW 1990. Isolation of DNA from fungal mycelia and single spores. In: Innis MA, Gelfand DH, Sninsky JJ and White TJ. PCR Protocols. A Guide to Methods and Applications. Academic Press, San Diego, CA. pp. 282-287.

Murakami S and Takemaru T 1990. Genetic studies of Pleurotus salmoneostramineus forming albino basidiocarps. Reports of the Tottori Mycological Institute 28: 199-204.

Nei M and Li WH 1979. Mathematical model for studying genetic variation in terms of restriction endonucleases. Proc. Natl. Acad. Sci. 76: 5269-5273. 
Park HG, Ko HG, Kim SH and Park WM 2004. Molecular identification of Asian isolates of medicinal mushroom Hericiumerinaceumby phylogenetic analysis of nuclear ITS rDNA. J. Microbiol. Biotechnol. 14: 816-821.

Ro HS, Kim SS, Ryu JS, Jeon CO, Lee TS and Lee HS 2007. Comparative studies on the diversity of the edible mushroom Pleurotuseryngii: ITS sequence analysis, RAPD fingerprinting and physiological characteristics. Myco. Res. 111: 710-715.

Saitou N and Nei M 1987. The neighbor-joining method: A new method for reconstructing phylogenetic trees. Mol. Biol. Evol. 4: 406-425.

Shim SM, Oh YH, Lee KR, Kim SH, Im KH, Kim JW, Lee UY, Shim JO, Shim MJ, Lee MW, Ro HS, Lee HS and Lee TS 2005. The characteristics of culture conditions for the mycelial growth of Macrolepiota procera. Mycobiology 33: 15-18.

Thompson JD, Higgins DG and Gibson TJ 1994. Clustal W: improving the sensitivity of progressive multiple sequence alignment through sequence weighing position-specific gap penalties and weight matrix choice. Nucleic Acids Res. 22: 4673-4680.

Tuchwell DS, Nicholson MJ, Mc-Sweeney CS, Theodorou MK and Brookman JL 2005. The rapid assessment of ruminal fungi to presumptive genera using ITS1 and ITS2 RNA secondary structures to produce group specific fingerprints. Microbiology 151: 1557-1567.

Venturella G. 2000. Typification of Pleurotusnebrodensis. Mycotaxon.75: 229-231.

White TJ, Bruns T, Lee S and Taylor J 1990. Amplification and direct sequencing of fungal ribosomal RNA genes for phylogenetics. In: Innis MA, Gelfand DH, Sninsky JJ and White TJ. PCR protocol: a guide to methods and applications. Academic press, SanDiego, CA. pp. 315-322.

Williams JGK, Kubelik AR, Livak KJ, Rafalski JA and Tingey SV 1990. DNA polymorphisms amplified by arbitrary primers are useful as genetic markers. Nucleic Acids Res. 18: 6531-6535.

Yoon KN, Alam N, Shim MJ and Lee TS2012. Hypolipidemic and antiatherogenesis effect of culinarymedicinal pink oyster mushroom, Pleurotus salmoneostramineus L. Vass. (Higher Basidiomycetes), in hypercholesterolemic rats. Int. J. Med. Mushrooms 14(1): 27-36.

Zervakis GI, Venturella G and Papadopoulou K 2001. Genetic polymorphism and taxonomic infrastructure of the Pleurotuseryngiispecies-complex as determined by RAPD analysis, isozyme profiles and ecomorphological characters. Microbiology 147: 3183-3194. 